\title{
Polymerase Chain Reaction Assays for the Detection and Discrimination of the Soybean Rust Pathogens Phakopsora pachyrhizi and P. meibomiae
}

\author{
Reid D. Frederick, Christine L. Snyder, Gary L. Peterson, and Morris R. Bonde
}

U.S. Department of Agriculture-Agricultural Research Service, Foreign Disease-Weed Science Research Unit, 1301 Ditto Avenue, Fort Detrick, MD 21702.

Accepted for publication 14 October 2001.

\begin{abstract}
Frederick, R. D., Snyder, C. L., Peterson, G. L., and Bonde, M. R. 2002. Polymerase chain reaction assays for the detection and discrimination of the soybean rust pathogens Phakopsora pachyrhizi and P. meibomiae. Phytopathology 92:217-227.

Soybean rust occurs in Australia and many countries throughout Africa, Asia, and South America. The causal agents of soybean rust are two closely related fungi, Phakopsora pachyrhizi and P. meibomiae, which are differentiated based upon morphological characteristics of the telia. Determination of the nucleotide sequence of the internal transcribed

spacer (ITS) region revealed greater than $99 \%$ nucleotide sequence similarity among isolates of either $P$. pachyrhizi or $P$. meibomiae, but only $80 \%$ sequence similarity between the two species. Utilizing differences within the ITS region, four sets of polymerase chain reaction (PCR) primers were designed specifically for $P$. pachyrhizi and two sets for $P$. meibomiae. Classical and real-time fluorescent PCR assays were developed to identify and differentiate between $P$. pachyrhizi and $P$. meibomiae. Identification of $P$. pachyrhizi from infected soybean leaves using the real-time PCR assay will allow for more rapid diagnoses.
\end{abstract}

Soybean rust has been reported in Australia, China, India, Japan, Taiwan, and Thailand in the Eastern Hemisphere and in Brazil, Colombia, Costa Rica, and Puerto Rico in the Western Hemisphere $(1,2)$. Soybean rust can be a devastating disease, with yield loses of up to 70 to $80 \%$ reported in some fields in Taiwan $(7,9)$. Plants that are heavily infected have fewer pods and smaller seeds that are of poor quality (9). Although soybean rust was found in Hawaii in 1994 (23), it has not yet been observed in the continental United States.

Two species of fungi, Phakopsora pachyrhizi Sydow and $P$. meibomiae (Arthur) Arthur, cause soybean rust (18). P. pachyrhizi occurs throughout Australasia as well as the islands of Japan, the Philippines, and Taiwan (18). The soybean rust pathogen recently reported in Hawaii (23) and Zimbabwe (C. Levy, personal communication) has been tentatively identified as $P$. pachyrhizi. $P$. meibomiae is found in South and Central America and the Caribbean (18).

Unlike other rusts, $P$. pachyrhizi and $P$. meibomiae infect an unusually broad range of plant species. $P$. pachyrhizi naturally infects 31 species in 17 genera of legumes, and 60 species in 26 other genera have been infected under controlled conditions (23). $P$. meibomiae naturally infects 42 species in 19 genera of legumes, and 18 additional species in 12 other genera have been artificially infected (23). Twenty-four plant species in 19 genera are hosts for both species (23).

Corresponding author: R. D. Frederick; E-mail address: frederir@ncifcrf.gov

The use of trade, firm, or corporation names in this publication (or page) is for the information and convenience of the reader. Such use does not constitute an official endorsement or approval by the United States Department of Agriculture or the Agricultural Research Service of any product or service to the exclusion of others that may be suitable.

Publication no. P-2001-1219-01R

This article is in the public domain and not copyrightable. It may be freely reprinted with customary crediting of the source. The American Phytopathological Society, 2002.
The recent findings of soybean rust in Hawaii and Zimbabwe, and the reemergence of the disease in India, has prompted fear that the pathogens are spreading to new geographic regions. If $P$. pachyrhizi were to gain entry into the continental United States and become established, serious losses would likely occur (26). It has been estimated that yield loses could exceed $10 \%$ in most of the United States and up to $50 \%$ in the Mississippi Delta and southeastern states $(23,26)$. Currently, there is no resistance to soybean rust in any of the U.S. commercial soybean cultivars. Some fungicides are effective against $P$. pachyrhizi by slowing the spread of the pathogen enough so that normal seed set and pod fill can occur (21). However, widespread fungicide applications on soybean fields in the United States are not deemed cost effective. As a result, this control option would be useful only for eradication on small acreages. Therefore, it is critical that rapid diagnostic methods be made available for detecting soybean rust at an early stage of infection to increase the chances of eradication.

Field identification of soybean rust often is difficult because symptoms may be confused with bacterial pustule caused by Xanthomonas axonopodis pv. glycines, especially during the early stages of disease development $(15,23,24)$. Even with a hand lens, the lesions of the two diseases on the upper leaf surface look very similar. Likewise, the raised dried blisters of the bacterial pustule lesions on the underside of the leaf appear similar to the uredinial cones of soybean rust (23). Therefore, a molecular-based diagnostic assay that is specific to the soybean rust pathogens, like polymerase chain reaction (PCR), would be extremely helpful in making an accurate and timely identification.

In this study, we report the development of both classical and real-time PCR assays for the rapid detection and discrimination of the soybean rust pathogens $P$. pachyrhizi and $P$. meibomiae. Preliminary results of this research have been reported previously (13).

\section{MATERIALS AND METHODS}

Microorganisms and growth conditions. The origin and source of $P$. pachyrhizi, $P$. meibomiae, and $X$. axonopodis pv. gly- 
cines isolates used in this study are shown in Table 1. The isolates are maintained at the USDA-ARS Foreign Disease-Weed Science Research Unit Plant Pathogen Containment Facility at Fort Detrick, MD (17) under Animal and Plant Health Inspection Service permit. P. pachyrhizi and P. meibomiae isolates were propagated by spray inoculation onto soybean cv. Williams and red kidney bean, respectively. Red kidney plants were used to propagate $P$. meibomiae isolates because they yield significantly more urediniospores than do soybean plants. Urediniospores were suspended in sterile distilled $\mathrm{H}_{2} \mathrm{O}$ containing $0.01 \%$ Tween $20(\mathrm{vol} / \mathrm{vol})$ at a concentration of 2,500 spores per $\mathrm{ml}$, and $2.5 \mathrm{ml}$ of inoculum was sprayed per plant onto either soybean or red kidney leaves with an atomizer attached to an air compressor. The plants were incubated overnight ( 14 to $18 \mathrm{~h}$ ) in dew chambers at $20^{\circ} \mathrm{C}$ and transferred to greenhouses where the temperature ranged from 18 to $30^{\circ} \mathrm{C}$. Plants inoculated with different $P$. pachyrhizi and $P$. meibomiae isolates were propagated in separate greenhouses to minimize the chance for cross-contamination. Urediniospores were harvested from infected leaves 10 to 14 days following inoculation and at subsequent weekly intervals with a mechanical spore harvester (11). Urediniospores were maintained in liquid nitrogen, and frozen spores were heat shocked at $40^{\circ} \mathrm{C}$ for $5 \mathrm{~min}$ and hydrated for 12 to $16 \mathrm{~h}$ prior to inoculation. $X$. axonopodis pv. glycines isolates were grown at $25^{\circ} \mathrm{C}$ on yeast extract-dextrose- $\mathrm{CaCO}_{3}$ medium (20).

DNA extraction and recombinant DNA techniques. For crude DNA preparations of $P$. pachyrhizi and P. meibomiae iso- lates, approximately 5 to $10 \mathrm{mg}$ of urediniospores of each isolate was placed onto the surface of sterile distilled $\mathrm{H}_{2} \mathrm{O}$ in petri plates $(50 \times 9 \mathrm{~mm})$, and the spores were allowed to germinate at room temperature $\left(20\right.$ to $22^{\circ} \mathrm{C}$ ) overnight. Mycelia was collected by filtration onto Whatman No. 1 filter paper, and the tissue was ground in $100 \mathrm{ml}$ of extraction buffer $(89 \mathrm{mM}$ Tris- $\mathrm{HCl}, \mathrm{pH} 8.0$, $45 \mathrm{mM}$ boric acid, $0.05 \mathrm{mM}$ EDTA, and $1.0 \%$ (vol/vol) $\beta$-mercaptoethanol) in microcentrifuge tubes by a plastic pestle attached to a power drill. Samples were incubated at $75^{\circ} \mathrm{C}$ for $15 \mathrm{~min}$ and centrifuged at $16,000 \times g$ for 10 min to pellet debris. The supernatants were transferred to new tubes and stored at $-20^{\circ} \mathrm{C}$ as DNA extracts. DNA from the Zimbabwe isolates, MUT and TM, was extracted as described previously from intact urediniospores without germination on sterile distilled $\mathrm{H}_{2} \mathrm{O}$.

Large-scale DNA isolations were conducted with approximately $1.0 \mathrm{~g}$ of urediniospores from either $P$. pachyrhizi isolate TW72-1 or $P$. meibomiae isolate PR. Spores were germinated on sterile distilled $\mathrm{H}_{2} \mathrm{O}$, and the mycelia were collected as described previously and frozen in liquid nitrogen. The frozen samples were ground by acid-washed glass beads in a mortar and pestle. Sixteen milliliters of grinding buffer (200 mM Tris-HCl, pH 8.0, $250 \mathrm{mM}$ $\mathrm{NaCl}, 25 \mathrm{mM}$ EDTA, and $0.5 \%$ [wt/vol] sodium dodecyl sulfate) was added, and samples were incubated on ice for $5 \mathrm{~min}$. An equal volume of Tris-saturated phenol was added to each sample and mixed by inverting. Sixteen milliliters of chloroform/isoamyl alcohol $(24: 1, \mathrm{vol} / \mathrm{vol})$ was added, and the samples were mixed as above. Samples were centrifuged at 10,000 $\times g$ (Sorvall SS-34;

TABLE 1. Isolates of Phakopsora pachyrhizi, P. meibomiae, and Xanthomonas axonopodis pv. glycines used in this study

\begin{tabular}{|c|c|c|c|c|}
\hline Isolate & Origin & Year & Host & Source \\
\hline \multicolumn{5}{|c|}{ P. pachyrhizi } \\
\hline AU72-1 & Australia & 1972 & Soybean & D. E. Bythe, Brisbane \\
\hline AU79-1 & Australia & 1979 & Soybean & Unknown \\
\hline HW95 & Hawaii & 1995 & Soybean & E. Kilgore, Oahu \\
\hline HW98 & Hawaii & 1998 & Soybean & E. Kilgore, Oahu \\
\hline IN73-1 & India & 1973 & Soybean & D. N. Thapliyal, Pantnagar \\
\hline ID72-1 & Indonesia & 1972 & Soybean & Unknown \\
\hline PH77-1 & Philippines & 1977 & Soybean & Bureau of Plant Industries Los Banos \\
\hline TW72-1 & Taiwan & 1972 & Soybean & Lung-Chi Wu, Taipei \\
\hline TW80-1 & Taiwan & 1980 & Soybean & AVRDC, Taiwan \\
\hline TW80-2 & Taiwan & 1980 & Soybean & AVRDC, Taiwan \\
\hline TH76-1 & Thailand & 1976 & Soybean & U. Pupipat, Pak Chang \\
\hline MUT & Zimbabwe & 2000 & Soybean & C. Levy, Mutare \\
\hline $\mathrm{TM}$ & Zimbabwe & 2000 & Soybean & C. Levy, Turk Mine \\
\hline \multicolumn{5}{|c|}{ P. meibomiae } \\
\hline BZ82-1 & Brazil & 1982 & Lima beans & J. A. Deslandes \\
\hline PR & Puerto Rico & Unknown & Several legume species and soybean & K. R. Bromfield \\
\hline \multicolumn{5}{|c|}{$X$. axonopodis pv. glycines } \\
\hline XP21 & Oklahoma & 1944 & Soybean & W. H. Burkholder \\
\hline XP22 & Oklahoma & 1944 & Soybean & W. H. Burkholder \\
\hline XP175 & Sudan & 1956 & Soybean & K. A. Sabet \\
\hline XP202 & Zimbabwe & 1961 & Soybean & A. C. Hayward \\
\hline
\end{tabular}

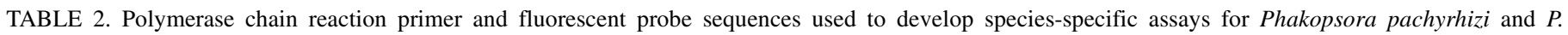
meibomiae

\begin{tabular}{|c|c|c|c|c|}
\hline Primer/probe & Sequence & Length & $\operatorname{Tm}^{\mathrm{a}}$ & $\% \mathrm{GC}^{\mathrm{b}}$ \\
\hline Ppa1 & 5'-TAAGATCTTTGGGCAATGGT-3' & 20 & $53.5^{\circ} \mathrm{C}$ & 40.0 \\
\hline Ppa2 & 5'-GCAACACTCAAAATCCAACAAT-3' & 22 & $55.4^{\circ} \mathrm{C}$ & 36.4 \\
\hline Ppa3 & 5'-CCCATTTAATTGGCTCATTG-3' & 20 & $54.4^{\circ} \mathrm{C}$ & 40.0 \\
\hline Ppa4 & 5'-TCAAAATCCAACAATTTCCC-3' & 20 & $53.7^{\circ} \mathrm{C}$ & 35.0 \\
\hline Pme1 & 5'-GAAGTTTTTGGGCAAATCAC-3' & 20 & $53.5^{\circ} \mathrm{C}$ & 40.0 \\
\hline Pme2 & $5^{\prime}$-GCACTCAAAATCCAACATGC- $3^{\prime}$ & 20 & $55.3^{\circ} \mathrm{C}$ & 45.0 \\
\hline Ppm1 & 5'-GCAGAATTCAGTGAATCATCAAG-3' & 23 & $55.3^{\circ} \mathrm{C}$ & 39.1 \\
\hline Ppm2 & 5'-CTCAAACAGGTGTACCTTTTGG- $3^{\prime}$ & 22 & $55.2^{\circ} \mathrm{C}$ & 45.5 \\
\hline FAM-probe & 5'-FAM-CCAAAAGGTACACCTGTTTGAGTGTCA-TAMRA-3' & 27 & $63.2^{\circ} \mathrm{C}$ & 44.4 \\
\hline VIC-probe & 5'-VIC-TGAACGCACCTTGCACCTTTTGGT-TAMRA-3' & 24 & $67.3^{\circ} \mathrm{C}$ & 50.0 \\
\hline
\end{tabular}

a Melting temperature; Tm was calculated at $(50 \mathrm{nM})$ primer and (50 nM) salt using the program Primer Express (Applied Biosystems).

b Percentage of guanulic and cytidylic acid. 
DuPont Instruments, Newtown, CT) for $10 \mathrm{~min}$ at $4^{\circ} \mathrm{C}$. The aqueous phase was transferred to a new tube, and $1 / 10$ volume of 3 M KOAc ( $\mathrm{pH} 5.5$ ) was added with 0.6 volumes of isopropanol. Samples were mixed by inverting and incubated at $-20^{\circ} \mathrm{C}$ for at least $30 \mathrm{~min}$. The samples were centrifuged at $12,000 \times g$ for $20 \mathrm{~min}$ as described previously, the supernatant was decanted, and the pellets were allowed to air dry. DNA pellets were resuspended and brought to $2.8 \mathrm{ml}$ with Tris-EDTA buffer. Three grams of $\mathrm{CsCl}$ and $200 \mathrm{ml}$ of ethidium bromide stock solution $(10 \mathrm{mg} / \mathrm{ml})$ were added, and the samples were mixed by inverting. The samples were transferred to quick-seal tubes (TL100; Beckman Instruments, Inc., Palo Alto, CA), balanced, and sealed by a heat-sealer (Beckman Instruments). The samples were centrifuged at $95,000 \times g$ at $15^{\circ} \mathrm{C}$ overnight (12 to $16 \mathrm{~h}$ ) in a tabletop ultracentrifuge (TL-100; Beckman Instruments). Following centrifugation, DNA bands were visualized with a long wavelength UV light (365 nm, Blak-Ray Model UVL-22; Ultra-Violet Products, San Gabriel, CA). DNA bands were removed with an 18 gauge needle and syringe, and the ethidium bromide and $\mathrm{CsCl}$ were extracted as described (3). The amount of DNA was quantified by spectrophotometry using a SmartSpec 3000 (Bio-Rad Laboratories, Richmond, CA) and confirmed by agarose gel electrophoresis by DNA standards. Purified DNA was stored at $-20^{\circ} \mathrm{C}$.

$X$. axonopodis pv. glycines isolates were grown at $25^{\circ} \mathrm{C}$ in nutrient broth (8 g/liter; Difco Laboratories, Detroit) for $20 \mathrm{~h}$, and genomic DNA was extracted with a genomic DNA purification kit (Wizard; Promega, Madison, WI) according to the manufacturer's directions.

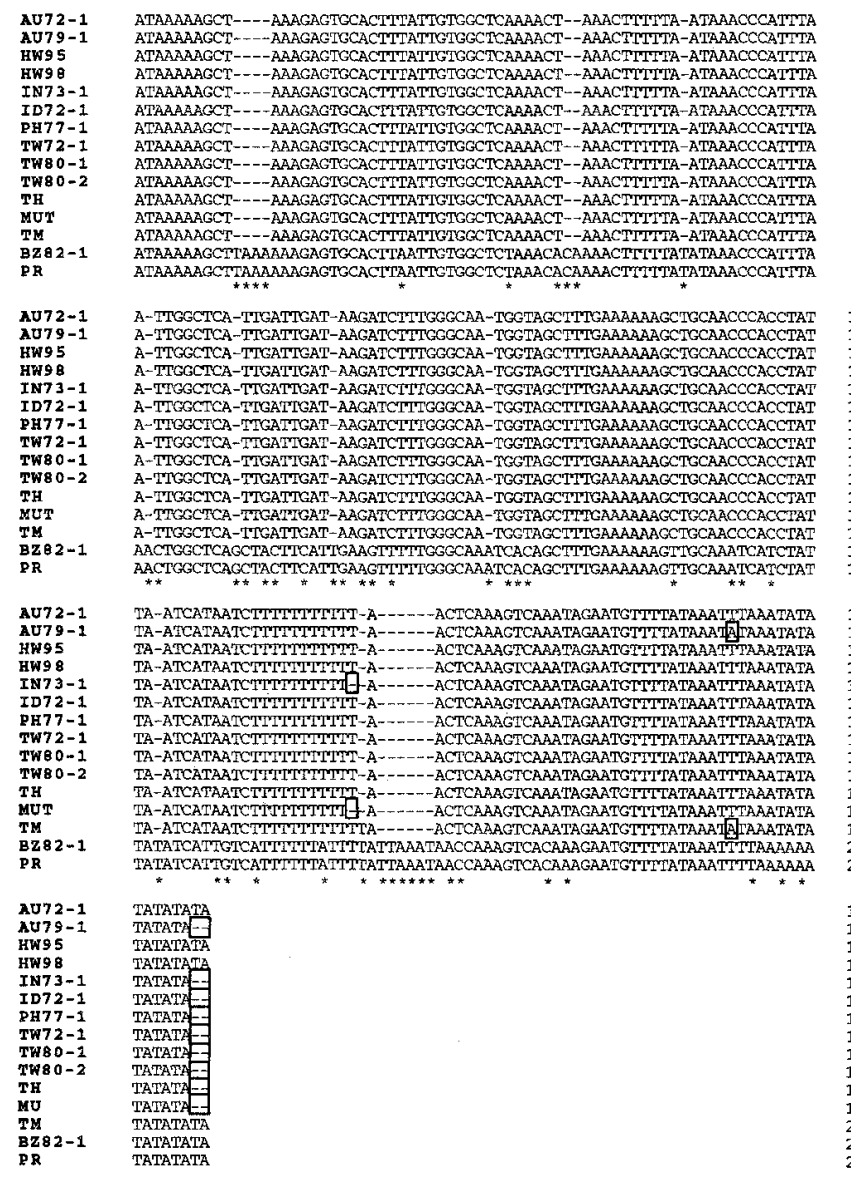

Fig. 1. Nucleotide sequence alignment of the internal transcribed spacer 1 region from Phakopsora pachyrhizi and P. meibomiae isolates (BZ82-1 and PR, respectively). Nucleotide differences that occur among either the $P$. meibomiae or $P$. pachyrhizi isolates are highlighted with open boxes, and differences between $P$. meibomiae and $P$. pachyrhizi isolates are denoted with an asterisk.
DNA was extracted from healthy and infected plant material approximately 10 to 14 days after inoculation with a plant DNA extraction kit (Nucleon Phytopure; Amersham Pharmacia Biotech, Piscataway, NJ) according to the manufacturer's directions. DNA was extracted from approximately $0.1 \mathrm{~g}$ of tissue per sample by pooling six leaf disks that were excised from plants with a number 5 cork borer (8-mm diameter).

The internal transcribed spacer (ITS) regions were cloned from $P$. pachyrhizi and $P$. meibomiae isolates by PCR using the primers ITS4 and ITS5 (25). The ITS regions were cloned into the TA cloning vector pCR2.1 (Invitrogen Corp., Carlsbad, CA) and transformed into competent E. coli INV $\alpha \mathrm{F}$ ' cells according to the manufacturer's directions. Two clones from two independent PCR amplifications were sequenced for each Phakopsora isolate.

DNA sequencing and analysis. Plasmid DNA was extracted with a plasmid mini-prep kit (Wizard; Promega) according to the manufacturer's directions. The concentration of DNA was determined by UV spectrometry at $260 \mathrm{~nm}$ by a SmartSpec 3000 (Bio-Rad), and the DNA was labeled with a sequencing kit (ABI Prism BigDye Terminator Cycle Sequencing Ready Reaction; Applied Biosystems, Inc., Foster City, CA). The nucleotide sequence was determined by capillary electrophoresis with a genetic analyzer (ABI Prism 310; Applied Biosystems). Nucleotide sequences were aligned using the Bestfit and Pileup programs of the Genetics Computer Group computer software package (version 9.0, Genetics Computer Group, Madison, WI) (12) at the Advanced Biomedical Computing Center of the National Cancer Institute, Frederick, MD.
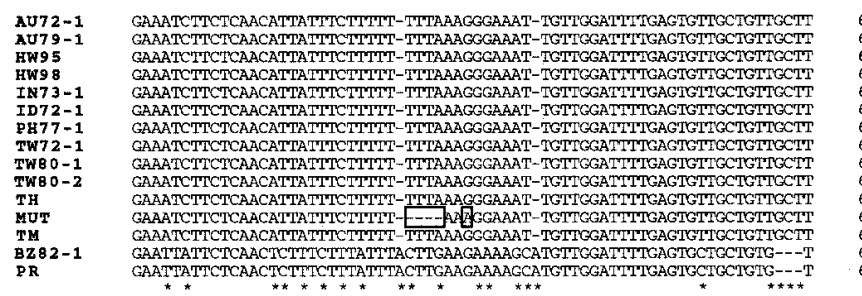

\section{AU72-1
AU79-1
HW95
HW98
TN73-1
ID72-1
PH77-1
TW72-1
TW72-1
TW80-1
TWBO-2
TH
MUT
TMT
MZ82-1
PR}

AU72-1
AU79-1
HW95
HW98
IN73-1
TD72-1
PH77-1
PW72-1
TW80-1
TWB0-2
TH
THT
MUT
TM
BZ82-1
PR

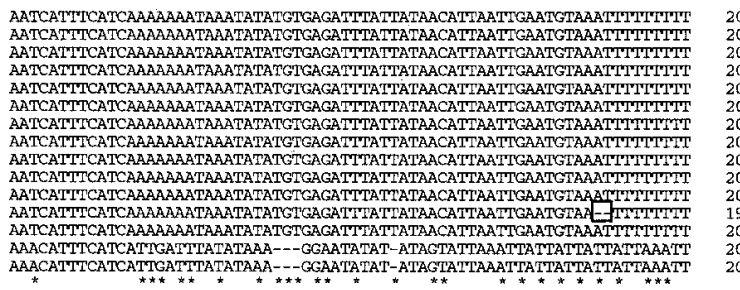

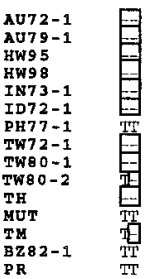

203
203
203
203
203
204
206
204
204
204
204
199
204
203
205

Fig. 2. Nucleotide sequence alignment of the internal transcribed spacer 2 region from Phakopsora pachyrhizi and P. meibomiae isolates (BZ82-1 and PR, respectively). Nucleotide differences that occur among either the $P$. meibomiae or $P$. pachyrhizi isolates are highlighted with open boxes, and differences between $P$. meibomiae and P. pachyrhizi isolates are denoted with an asterisk. 
PCR assay and Southern blot analysis. Oligonucleotide primers specific to $P$. pachyrhizi, $P$. meibomiae, or to both species were synthesized (Life Technologies/Gibco BRL, Gaithersburg, MD) to unique sequences within the ITS regions (Table 2). Classical PCR reactions were conducted in a thermocycler (Gene AMP PCR System 9700; Applied Biosystems) with 5 to $25 \mathrm{ng}$ of genomic DNA. PCR assays were performed in a total volume of $25 \mu$ containing $10 \mathrm{mM}$ Tris- $\mathrm{HCl} ; 50 \mathrm{mM} \mathrm{KCl}(\mathrm{pH} 8.3) ; 1.5 \mathrm{mM}$ $\mathrm{MgCl}_{2} ; 0.001 \%$ (wt/vol) gelatin; dATP, dGTP, dCTP, and dTTP, each at a concentration of $100 \mu \mathrm{M}$; each primer at a concentration of $1.0 \mu \mathrm{M}$; and 0.5 units of AmpliTaq DNA polymerase (Applied Biosystems). The PCR assays were performed with the following cycling conditions: $94^{\circ} \mathrm{C}$ denaturation for $1 \mathrm{~min}, 25$ cycles of $94^{\circ} \mathrm{C}$ for $15 \mathrm{~s}, 65^{\circ} \mathrm{C}$ for $15 \mathrm{~s}$, and $72^{\circ} \mathrm{C}$ for $15 \mathrm{~s}$, followed by an extension of $72^{\circ} \mathrm{C}$ for $6 \mathrm{~min}$.

Negative controls were tested by the same reaction mixture and amplification conditions described previously without template DNA. PCR products were analyzed by electrophoresis on $4.0 \%$ agarose (3:1 High Resolution Blend; Amresco, Solon, $\mathrm{OH}$ ) gels in $0.5 \times$ Tris-borate-EDTA buffer stained with ethidium bromide (3). Southern blots, labeling of DNA probes, and hybridization and chemiluminescent detection were as described previously (14).

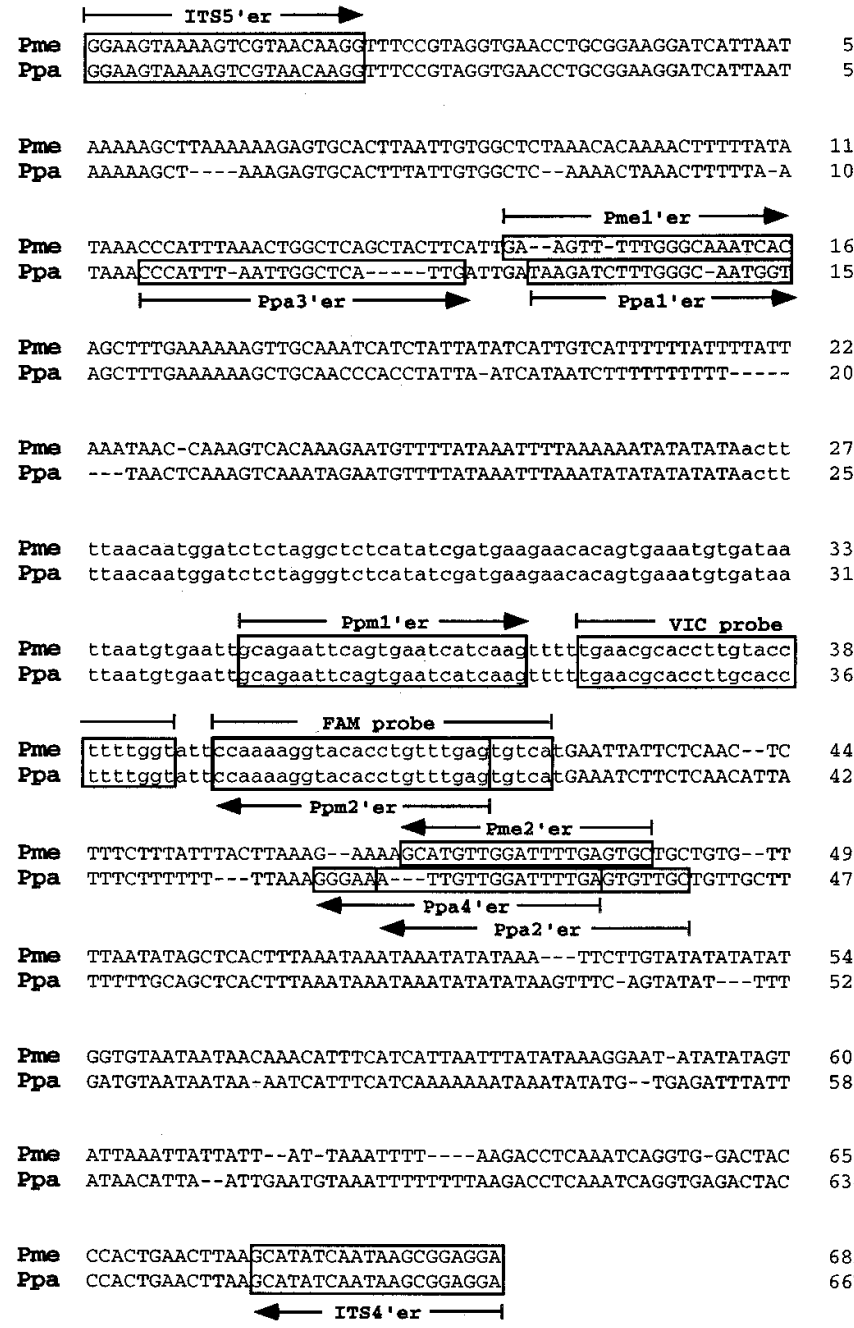

Fig. 3. Nucleotide sequence consensus alignment of the internal transcribed spacer 1 (ITS1), 5.8S, and ITS2 regions between Phakopsora pachyrhizi and $P$. meibomiae. The 5.8S rDNA is delineated by lowercase. The location of the $P$. pachyrhizi- and $P$. meibomiae-specific polymerase chain reaction (PCR) primers and the VIC- and FAM-labeled fluorescent probe sequences are delimited by boxes. The $5^{\prime}$ to $3^{\prime}$ direction of the PCR primers is shown by arrows.
The ITS region from $P$. pachyrhizi TW72-1 and $P$. meibomiae PR were used as hybridization probes.

TaqMan $5^{\prime}$ nuclease PCR assay. The $5^{\prime}$ nuclease assays were performed with a sequence detection system (ABI Prism 7700; Applied Biosystems) in a total of $25 \mu \mathrm{l}$ as described (14). The cycling conditions were as follows: $50^{\circ} \mathrm{C}$ for $2 \mathrm{~min}, 95^{\circ} \mathrm{C}$ for $10 \mathrm{~min}$, and 35 cycles of $95^{\circ} \mathrm{C}$ for $15 \mathrm{~s}$ and $60^{\circ} \mathrm{C}$ for $1 \mathrm{~min}$. The Ppm1/Ppa2 and Ppm1/Pme2 primer combinations were used at final concentration of $300 \mathrm{nM}$ with both FAM-probe and VICprobe, whereas the Ppm1/Ppm2 primer set was used at a final concentration of $900 \mathrm{nM}$ with the VIC-probe. The TaqMan probes, FAM-probe and VIC-probe (Table 2), were labeled at the $5^{\prime}$ end with the fluorescent reporter dyes 6-carboxy-fluorescin (FAM) and VIC, respectively, and both were labeled at the $3^{\prime}$ end with the quencher dye, 6-carboxy-tetramethyl-rhodamine (TAMRA) (Applied Biosystems). The probes were used at $400 \mathrm{nM}$ in both the $P$. pachyrhizi- and $P$. meibomiae-specific assays. The dilution series of genomic DNA from $P$. pachyrhizi isolate TW72-1 and $P$. meibomiae isolate $\mathrm{PR}$ were made in sterile distilled $\mathrm{H}_{2} \mathrm{O}$. Two independent replications were analyzed with duplicate DNA samples for each isolate per assay.

Data acquisition and analysis were done with the TaqMan data worksheet and software according to the manufacturer's instructions (Applied Biosystems). The $\Delta \mathrm{RQ}$ is defined as an increase in the emission intensity ratio of the reporter dye after release from the quencher dye on the fluorescent probe $\left(\mathrm{RQ}^{+}\right)$minus the baseline emission intensity of the quenched reporter dye on the intact fluorescent probe $\left(\mathrm{RQ}^{-}\right)$, or $\Delta \mathrm{RQ}=\left(\mathrm{RQ}^{+}\right)-\left(\mathrm{RQ}^{-}\right)$. The cycle threshold $(\mathrm{Ct})$ values for each reaction were calculated automatically by the ABI Prism sequence detection software by determining the point in time (PCR cycle number) at which the reporter fluorescence exceeds background.

Nucleotide sequence accession numbers. The nucleotide sequence of the ITS1-5.8S-ITS2 regions from the P. pachyrhizi and $P$. meibomiae isolates from this study have been deposited as GenBank Accession Nos. AF333488 to AF333502.

\section{RESULTS}

Sequence comparison of the $P$. pachyrhizi and $P$. meibomiae ITS regions. A nucleotide sequence comparison of the ITS1 (Fig. 1) and ITS2 (Fig. 2) regions of the $P$. pachyrhizi and $P$. meibomiae isolates is shown. The ITS1 region ranged in size from 196 to 199 nucleotides for the $P$. pachyrhizi isolates and $218 \mathrm{nu}-$ cleotides for the $P$. meibomiae isolates. Among the $P$. pachyrhizi isolates, variation or gaps were observed at four nucleotide positions (Fig. 1), with greater than $98.0 \%$ sequence identity among the isolates. No variation was observed between the two $P$. meibomiae isolates. A comparison between the P. pachyrhizi and $P$. meibomiae ITS1 regions revealed 49 nucleotide differences or gaps (Fig. 1), representing $77.5 \%$ sequence identity between these two Phakopsora spp. The ITS2 region ranged in size from 199 to 206 nucleotides for the $P$. pachyrhizi isolates and 203 and $205 \mathrm{nu}-$ cleotides for the two $P$. meibomiae isolates, BZ82-1 and PR, respectively. Ten nucleotide differences or gaps were found between the $P$. pachyrhizi isolates (greater than $95.0 \%$ identity), whereas two additional nucleotides were found in the $P$. meibomiae PR isolate relative to the BZ82-1 isolate (greater than $99.0 \%$ identity). A comparison of the P. pachyrhizi and P. meibomiae ITS2 regions revealed 64 nucleotide differences or gaps (Fig. 2) or approximately $68.5 \%$ sequence identity between the species.

An alignment of the ITS1 and ITS2 nucleotide sequences of the rust isolates from Hawaii (HW95 and HW98) and Zimbabwe (MUT and TM) with P. pachyrhizi and P. meibomiae indicated that these isolates are $P$. pachyrhizi.

Selection of species-specific primers and the development of PCR assays. Because the nucleotide sequence comparisons of the ITS1 and ITS2 regions revealed significant divergence between 
the $P$. pachyrhizi and $P$. meibomiae isolates, sequence sites were selected for PCR primer design that utilize these differences. PCR primers Ppa1, Ppa2, Ppa3, and Ppa4 (for $\underline{P}$. pachyrhizi) are designed specifically to $P$. pachyrhizi sequences, whereas the primers Pme 1 and Pme2 (for $\underline{P}$. meibomiae) are directed at $P$. meibomiae sequences (Fig. 3; Table 2). The primers Ppm1 and Ppm2 (for $\underline{P}$. pachyrhizi and meibomiae) are aimed at the 5.8S rDNA region that is conserved between P. pachyrhizi and P. meibomiae (Fig. 3; Table 2). Four pairs of PCR primers were selected for specificity to $P$. pachyrhizi. The primer sets, Ppa1/Ppa2, Ppa3/Ppa4, Ppm1/Ppa2, and Ppm1/Ppa4 amplified PCR products of 332, 347, 141, and $136 \mathrm{bp}$, respectively, from $P$. pachyrhizi isolate TW72-1 but yielded no product from P. meibomiae isolate PR (Fig. 4A, B, $\mathrm{D}$, and E). Two sets of PCR primers were designed specifically for $P$. meibomiae, Pme1/Pme2 and Ppm1/Pme2, that amplified PCR products of 338 and $139 \mathrm{bp}$, respectively, from $P$. meibomiae isolate PR but not from P. pachyrhizi isolate TW72-1 (Fig. 4C and F). The primer set Ppm1/Ppm2 amplified a 79-bp PCR product from both $P$. pachyrhizi isolate TW72-1 and $P$. meibomiae isolate PR (Fig. 4G).

To determine the sensitivity limits of the $P$. pachyrhizi- and $P$. meibomiae-specific assays, dilutions of purified total DNA from $P$. pachyrhizi isolate TW72-1 and $P$. meibomiae isolate PR were tested with the PCR primer sets Ppm1/Ppa2, Ppm1/Ppa4, Ppm1/Pme2, and Ppm1/Ppm2 (Fig. 5). In the P. pachyrhizi-specific assays employing either primer set Ppm1/Ppa2 or Ppm1/Ppa4, a PCR product was detected on agarose gels and by Southern blots using as little as $0.1 \mathrm{ng}$ and $10 \mathrm{pg}$ of TW72-1 template DNA, respectively (Fig. 5A and B). The limit of detection was $10 \mathrm{ng}$ of PR template DNA by agarose gel and by Southern blot for the $P$. meibomiae-specific assay with the PCR primer set Ppm1/Pme2 (Fig. 5D). The PCR primer combination Ppm1/Ppm2, which amplifies a DNA product from both $P$. pachyrhizi and $P$. meibomiae, yielded a PCR product on an agarose gel and by a Southern blot using $0.1 \mathrm{ng}$ and $0.1 \mathrm{pg}$ of TW72-1 DNA, respectively (Fig. 5C). However, with this primer pair combination, the sensitivity of detection of a PCR product on both an agarose gel and a Southern blot was reduced to $1 \mathrm{ng}$ of template DNA from $P$. meibomiae isolate PR (Fig. 5E).

To determine the specificity of the $P$. pachyrhizi and $P$. meibomiae PCR primers, crude total DNA extracts from germinating urediniospores of $P$. pachyrhizi and $P$. meibomiae isolates from different geographic regions (Table 1) were tested with the PCR primers. The PCR primers Ppm1/Ppa2 and Ppm1/Ppa4 amplified a PCR product using DNA extracted from all $11 P$. pachyrhizi isolates, but no PCR product was detected from either of the P. meibomiae isolates (Fig. 6A and B). The Ppm1/Pme2 primer set amplified a single PCR product only from DNA extracted from the two $P$. meibomiae isolates, and no PCR product was detected from the P. pachyrhizi isolates (Fig. 6C). The primer set Ppm1/Ppm2 amplified a PCR product of $79 \mathrm{bp}$ from each of the P. pachyrhizi and P. meibomiae isolates tested (Fig. 6D). Southern blots confirmed the identity of the PCR products for each of the PCR assays by hybridization.

In order to verify the specificity of the $P$. pachyrhizi and $P$. meibomiae PCR primers, DNA extracted from four $X$. axonopodis pv. glycines isolates was tested using the Ppm1/Ppa2, Ppm1/Pme2, and Ppm1/Ppm2 primer sets. No detectable DNA product was found using DNA from the $X$. axonopodis pv. glycines isolates (data not shown). In control PCR reactions using primers $27 \mathrm{~F}\left(5^{\prime}\right.$ -
A

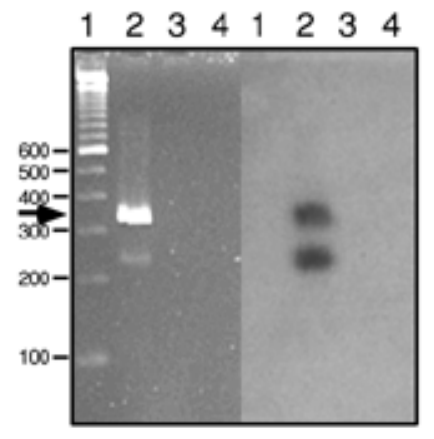

B

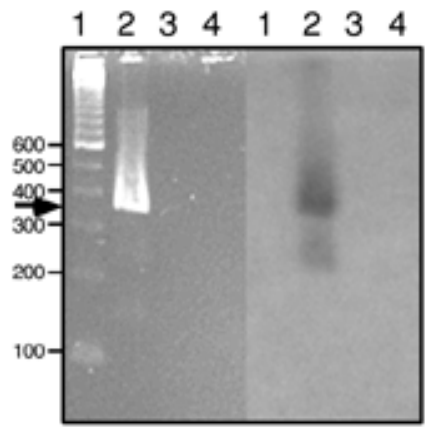

C

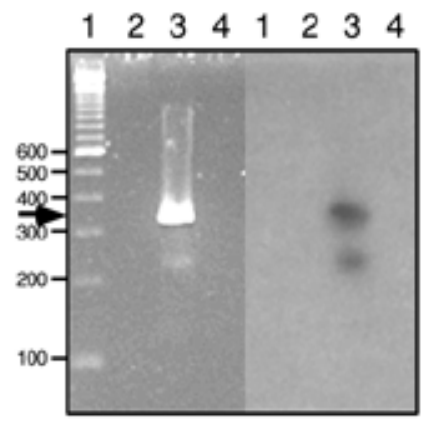

D

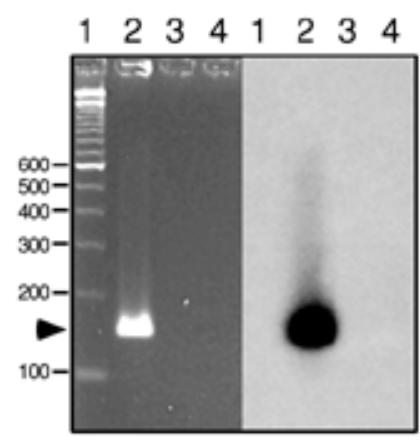

E

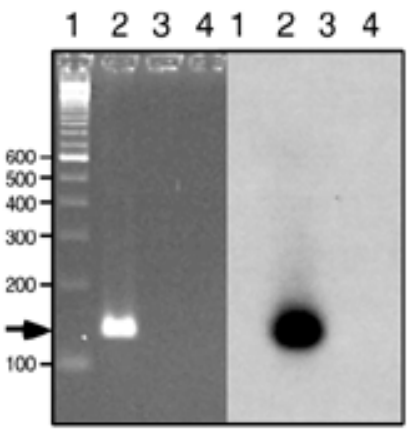

$\mathrm{F}$

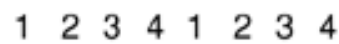

G

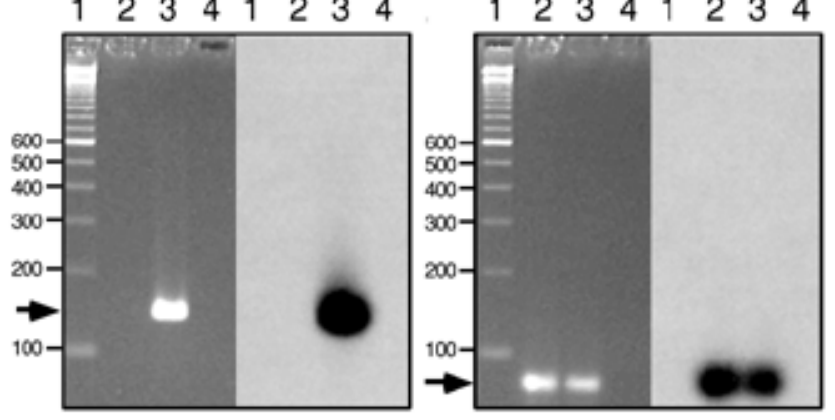

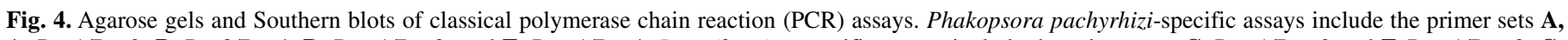

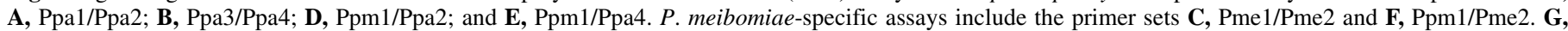

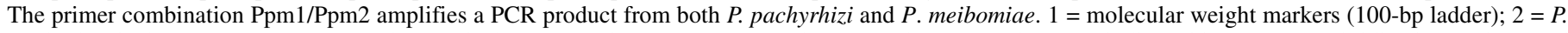

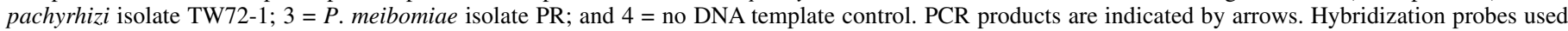
were the internal transcribed spacer regions from A, B, D, E, and G, TW72-1 and $\mathbf{C}$ and F, BZ82-1. 
A

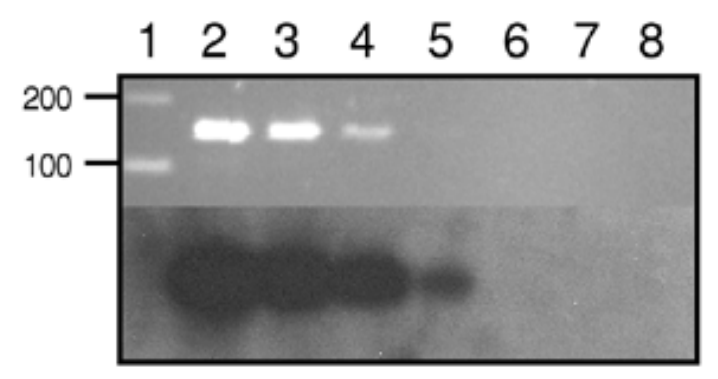

B

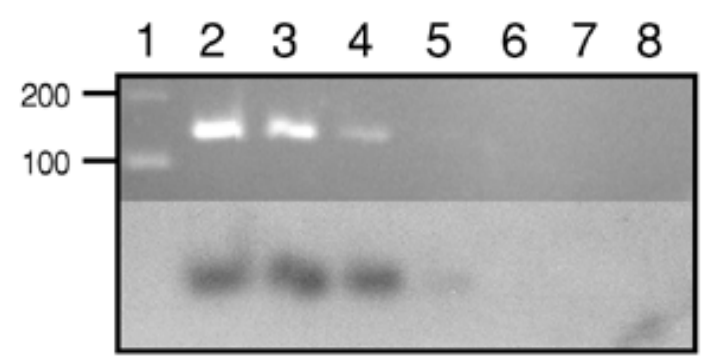

C

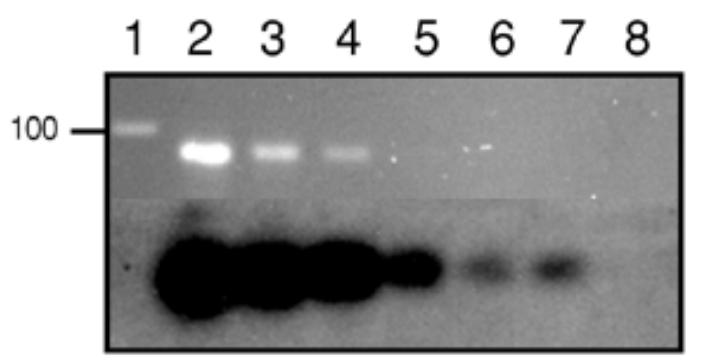

$\mathrm{D}$

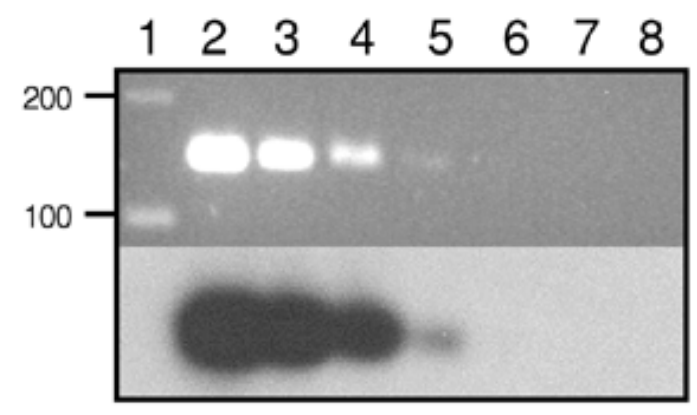

E

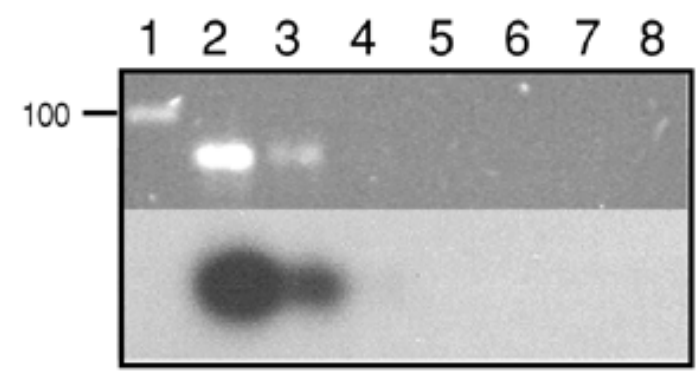

Fig. 5. Sensitivity of classical polymerase chain reaction (PCR) assays as detected by agarose gels and Southern blots. Phakopsora pachyrhizi-specific assays include the primer sets $\mathbf{A}, \mathrm{Ppm} 1 / \mathrm{Ppa} 2$ and $\mathbf{B}, \mathrm{Ppm} 1 / \mathrm{Ppa} 4$. D, $P$. meibomiae-specific assay is shown with the primer set Ppm1/Pme2. The primer combination $\mathrm{Ppm} 1 / \mathrm{Ppm} 2$ amplifies a PCR product from both $\mathbf{C}$ and E, $P$. pachyrhizi and $P$. meibomiae. DNA dilutions of $\mathbf{A}, \mathbf{B}$, and $\mathbf{C}, P$. pachyrhizi isolate TW72-1 and $\mathbf{D}$ and E, $P$. meibomiae PR were used at the following concentrations: $10 \mathrm{ng}(2), 1 \mathrm{ng}(3), 0.1 \mathrm{ng}(4), 10 \mathrm{pg}$ (5), $1 \mathrm{pg}(6)$, and $0.1 \mathrm{pg}(7) .1=$ molecular weight markers $(100$-bp ladder $)$ and $8=$ no DNA template control. Hybridization probes used were the internal transcribed spacer regions from $\mathbf{A}, \mathbf{B}$, and $\mathbf{C}$, TW72-1 and $\mathbf{D}$ and E, BZ82-1.
AGAGTTTGATCATGGCTCAG-3') and 383R (5'-CATGGCTGGATCAGGCTT-3') that are specific to conserved regions of the $16 \mathrm{~S}$ rRNA gene of bacteria (10), a 391-bp DNA band was amplified using the DNA extracted from the $X$. axonopodis pv. glycines isolates (data not shown).

TaqMan $5^{\prime}$ nuclease assay. Real-time PCR assays were developed for the TaqMan system by an internal fluorogenic probe with either the $P$. pachyrhizi-specific primer set Ppm1/Ppa2 or the $P$. meibomiae-specific primer set Ppm1/Pme2. Two different probe sequences common to both species were selected, and one was labeled with 6 '-FAM and the other with VIC. The amplicons were 136 and $139 \mathrm{bp}$ for the $P$. pachyrhizi- and P. meibomiaespecific assays, respectively (Fig. 3). The primer set Ppm1/Ppm2 yields a 79-bp amplicon using template DNA of either $P$. pachyrhizi or $P$. meibomiae. The $\Delta \mathrm{RQ}$ values were measured following each amplification cycle, and amplification plots of $P$. pachyrhizi isolate TW72-1 and P. meibomiae isolate BZ82-1 are shown for each assay (Fig. 7). In the P. pachyrhizi-specific TaqMan assay, the results were similar regardless of the probe used (Fig. 7A). The TW72-1 sample had Ct values of 18.51 (FAM-probe) and

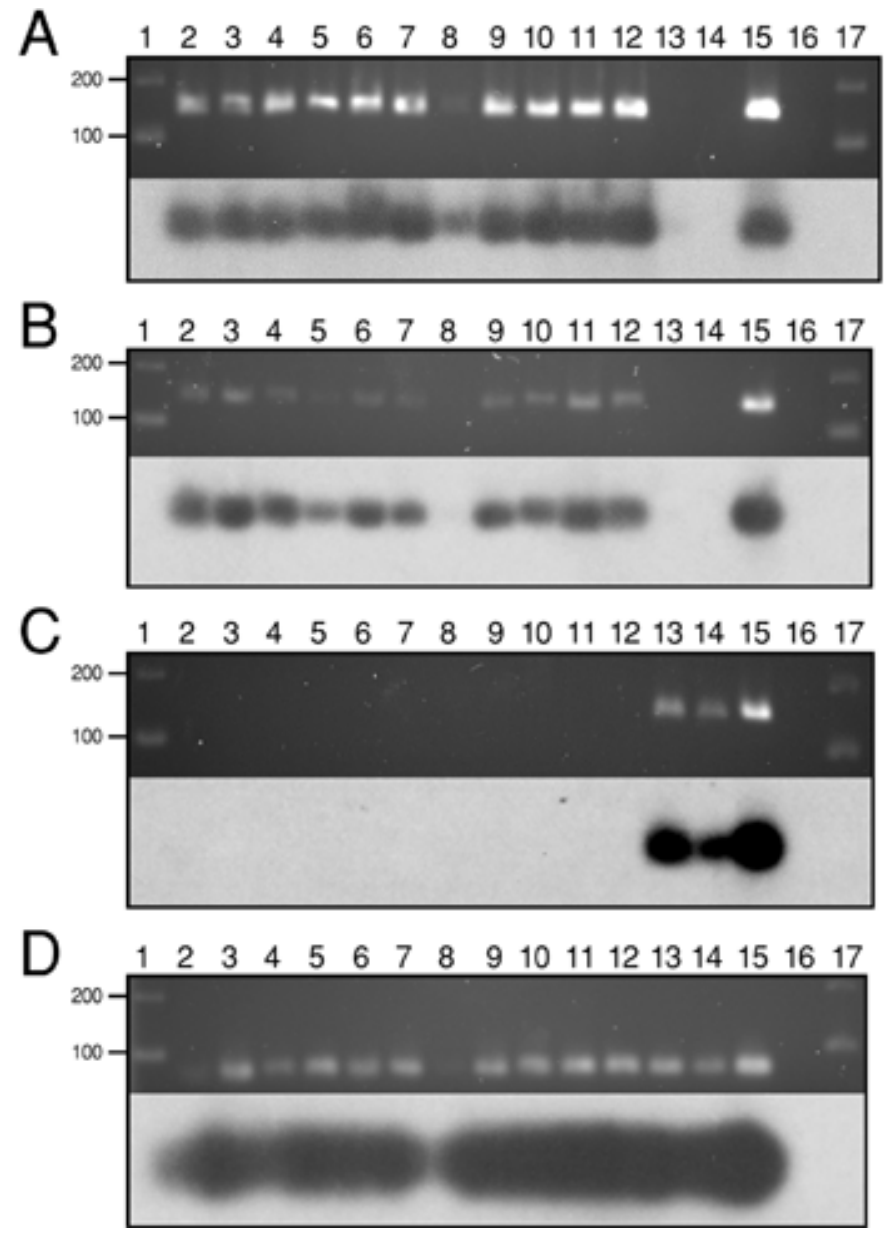

Fig. 6. Classical polymerase chain reaction (PCR) assays of Phakopsora pachyrhizi and $P$. meibomiae isolates. Agarose gels and Southern blots of $P$. pachyrhizi-specific assays with the primer sets $\mathbf{A}, \mathrm{Ppm} 1 / \mathrm{Ppa} 2$ and $\mathbf{B}$, Ppm1/Ppa4, and of $\mathbf{C}$, the $P$. meibomiae-specific assay with the primer set Ppm1/Pme2. D, The primer combination Ppm1/Ppm2 amplifies a PCR product from both $P$. pachyrhizi and $P$. meibomiae. Lanes 1 and $17=$ molecular weight markers (100-bp ladder), $2=$ AU72-1, $3=$ AU79-1, $4=$ IN73-1, $5=$ ID72-1, 6 = PH77-1, 7 = TW72-1, $8=$ TW80-1, $9=$ TW80-2, $10=$ TH, $11=$ HW95, 12 = HW98, 13 = BZ82-1, 14 = PR, $15=$ control plasmid DNA containing the internal transcribed spacer $1 / 2$ (ITS1/2) region from either $\mathbf{A}, \mathbf{B}$, and D, AU72-1 or C, BZ82-1, and 16 = no DNA template control. Hybridization probes used were the ITS regions from A, B, and D, TW72-1 and C, BZ82-1. 
19.36 (VIC-probe), whereas the BZ82-1 sample had Ct values of greater than 35 . The $\triangle \mathrm{RQ}$ value of the TW72-1 sample assayed with the FAM-probe was slightly higher than with the VIC-probe (Fig. 7A). In the P. meibomiae-specific TaqMan assay (Fig. 7B), the BZ82-1 sample had $\mathrm{Ct}$ values of 20.36 (FAM-probe) and
20.60 (VIC-probe), whereas the TW72-1 sample had Ct values of greater than 35. Once again, the use of the FAM- or VIC-probes did not affect $\mathrm{Ct}$ values, but the $\triangle \mathrm{RQ}$ values were slightly higher with the FAM-probe (Fig. 7B). Finally, in the TaqMan assay with the Ppm1/Ppm2 primer set and the VIC-probe, the TW72-1 and
A

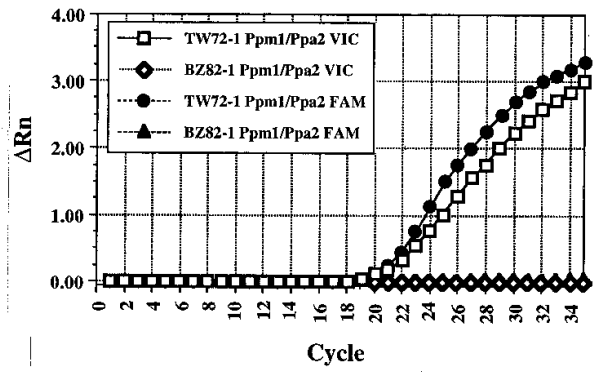

B

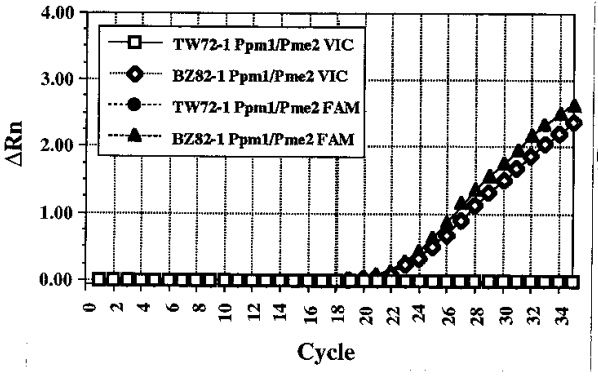

$\mathrm{C}$

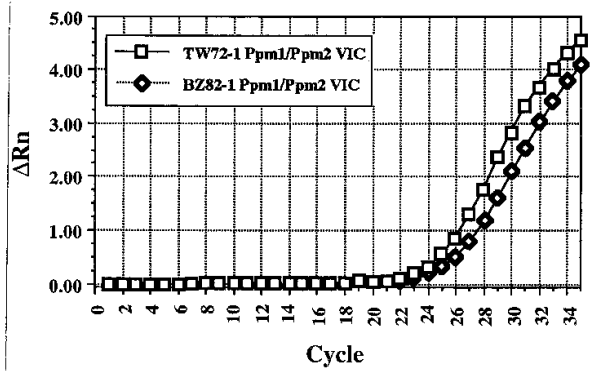

Fig. 7. Real-time polymerase chain reaction (PCR) amplification of DNA from Phakopsora pachyrhizi isolate TW72-1 and P. meibomiae isolate BZ82-1 by TaqMan PCR using a sequence detection system (ABI Prism 7700). A, P. pachyrhizi-specific flanking primers Ppm1/Ppa2, B, P. meibomiae-specific flanking primers Ppm1/Pme2, or $\mathbf{C}$, the primers Ppm1/Ppm2, which amplify a PCR product from both $P$. pachyrhizi and $P$. meibomiae were used with either a $5^{\prime}$-FAMor $5^{\prime}$-VIC-labeled internal probe sequence. The left axis $(\Delta \mathrm{RQ})$ is the change in fluorescence that is a measure of probe cleavage efficiency, and the bottom axis is the PCR cycling stage. Two independent assays were analyzed with duplicate DNA samples for each isolate.

A

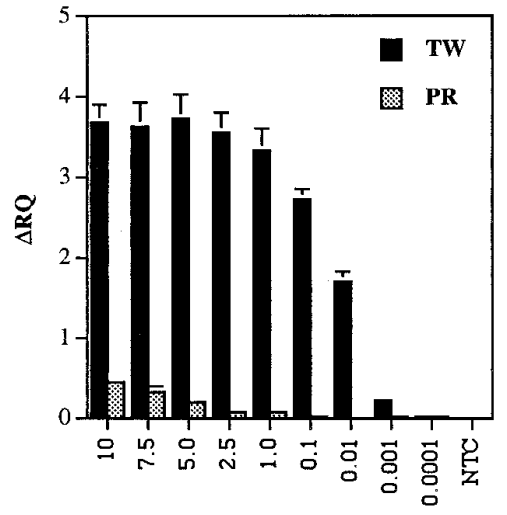

Amount of DNA
B

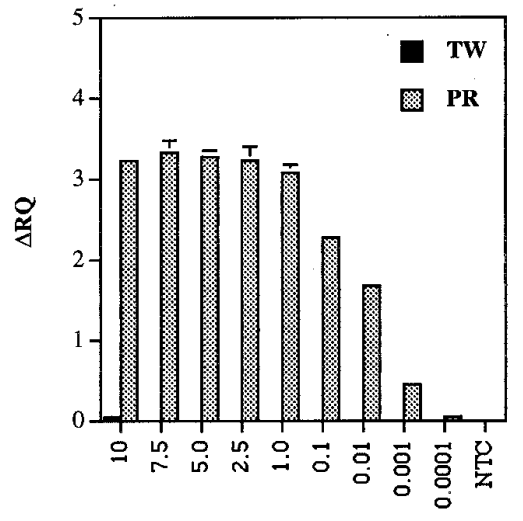

Amount of DNA
C

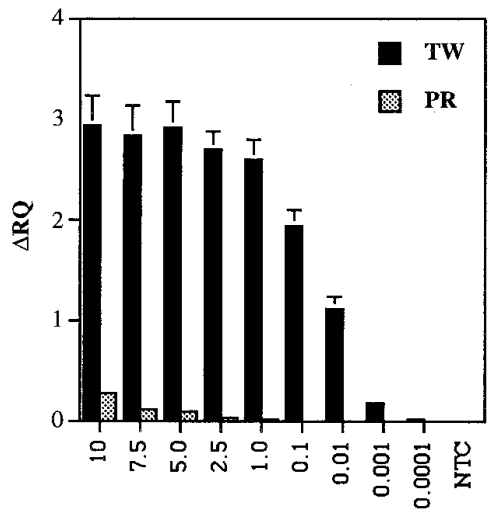

Amount of DNA
D

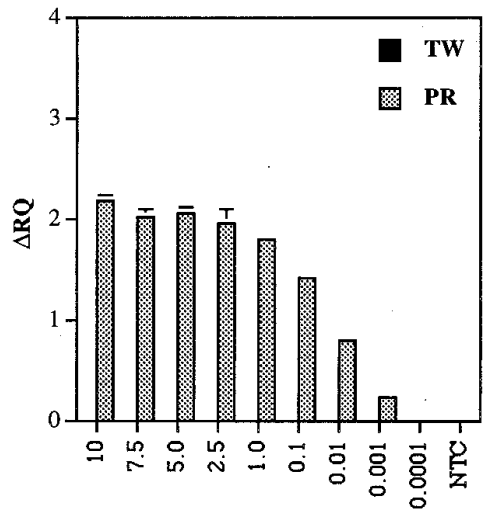

Amount of DNA
E

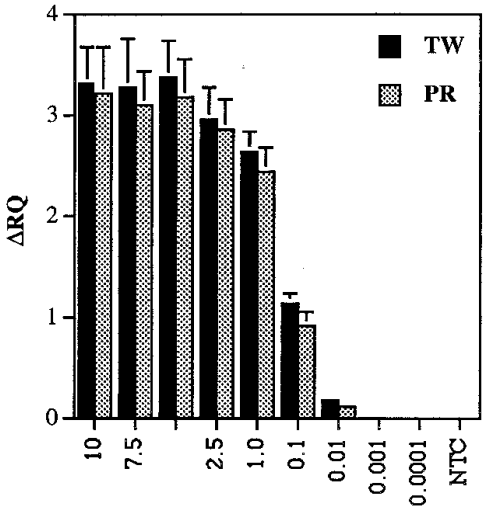

Amount of DNA

Fig. 8. Sensitivity of the Phakopsora pachyrhizi- and P. meibomiae-specific real-time polymerase chain reaction (PCR) assays. Specific amplification of DNA dilutions from P. pachyrhizi isolate TW72-1 and P. meibomiae isolate PR after 35 cycles of amplification using a TaqMan sequence detection system (ABI Prism 7700). A, P. pachyrhizi-specific flanking primers Ppm1/Ppa2 with a 5'-FAM-labeled internal probe sequence, B, $P$. meibomiae-specific flanking primers Ppm1/Pme2 with a 5'-FAM-labeled internal probe sequence, C, $P$. pachyrhizi-specific flanking primers Ppm1/Ppa2 with a 5'-VIC-labeled internal probe sequence, D, $P$. meibomiae-specific flanking primers Ppm1/Pme2 with a $5^{\prime}$-VIC-labeled internal probe sequence, and $\mathbf{E}$, the primers Ppm1/Ppm2, which amplify a PCR product from both P. pachyrhizi and $P$. meibomiae with a $5^{\prime}$-VIC-labeled internal probe sequence. The left axis ( $\left.\Delta \mathrm{RQ}\right)$ is the change in fluorescence that is a measure of probe cleavage efficiency, and the bottom axis is the PCR cycling stage. The $\triangle \mathrm{RQ}$ values are the means of two independent assays with duplicate DNA samples for each isolate. Error bars represent standard errors of the means. 
BZ82-1 samples had Ct values of 20.32 and 21.69, respectively, and the $\triangle R Q$ values of the TW72-1 sample was slightly higher than the BZ82-1 sample (Fig. 7C).

To determine the sensitivity limits of the real-time PCR assays, serial dilutions of purified total DNA of $P$. pachyrhizi isolate TW72-1 and P. meibomiae isolate PR were tested as DNA templates in each of the assays (Fig. 8). In the P. pachyrhizi-specific assay, $1 \mathrm{pg}$ of total template DNA from TW72-1 produced detectable levels of fluorescence with either the FAM-probe or the VIC-probe (Fig. 8A and C). Likewise, fluorescence was detected at $1 \mathrm{pg}$ of total DNA from isolate PR in the P. meibomiae assay with either probe (Fig. 8B and D). The sensitivity limits were reduced 10-fold $(10 \mathrm{pg})$ for detection of TW72-1 and PR in the TaqMan assay with the primer set Ppm1/Ppm2 and the VIC-probe (Fig. 8E).

In order to assess the accuracy of the real-time PCR assays, crude DNA extractions from $11 P$. pachyrhizi and $2 P$. meibomiae isolates were tested as templates in the assays. For the $P$. pachyrhizi assay, all $11 P$. pachyrhizi isolates had $\Delta \mathrm{RQ}$ values of greater than 2.320 , whereas $\Delta \mathrm{RQ}$ values of the $P$. meibomiae isolates did not exceed 0.735 with either the FAM-probe or VIC-probe (Table
3). In addition, all $11 P$. pachyrhizi isolates had $\mathrm{Ct}$ values less than 29.35, whereas Ct values of the P. meibomiae isolates exceeded 35 (Table 4). Conversely, in the $P$. meibomiae assay, the $P$. meibomiae isolates had $\triangle \mathrm{RQ}$ values greater than 2.455 , whereas the $\Delta \mathrm{RQ}$ values of the P. pachyrhizi isolates did not exceed 0.810 (Table 3). Furthermore, the $P$. meibomiae isolates had $\mathrm{Ct}$ values of less than 22.61, whereas the $\mathrm{Ct}$ values of the $P$. pachyrhizi isolates were greater than 35 (Table 4). Finally, in the TaqMan assay with the Ppm1/Ppm2 primers, the $\Delta \mathrm{RQ}$ values exceeded 2.010 for all of the $P$. pachyrhizi and $P$. meibomiae isolates compared with 0.400 for the no template control (Table 3). None of the $X$. axonopodis pv. glycines isolates had detectable $\Delta \mathrm{RQ}$ or $\mathrm{Ct}$ values in any of the real-time PCR assays (Tables 3 and 4).

Detection of Phakopsora spp. from infected plant tissue. The classical and real-time PCR assays were evaluated by infected soybean leaf tissue. In the $P$. pachyrhizi-specific classical PCR assay, soybean plants infected with $P$. pachyrhizi isolate TW72-1 produced a visible PCR product on an agarose gel and Southern blot, whereas the plants infected with P. meibomiae isolate BZ821 did not (Fig. 9A). Conversely, soybean plants infected with $P$. meibomiae isolate BZ82-1 yielded a DNA band on an agarose gel

TABLE 3. The end-point $(\Delta \mathrm{Rn})$ fluorescence results from real-time polymerase chain reaction assays of Phakopsora pachyrhizi and P. meibomiae isolates ${ }^{\mathrm{a}}$

\begin{tabular}{|c|c|c|c|c|c|}
\hline \multirow[b]{2}{*}{ Isolate } & \multicolumn{2}{|c|}{ Ppm1/Ppa2 primers } & \multicolumn{2}{|c|}{ Ppm1/Pme2 primers } & \multirow{2}{*}{$\frac{\text { Ppm1/Ppm2 primers }}{\text { VIC-probe }}$} \\
\hline & FAM-probe & VIC-probe & FAM-probe & VIC-probe & \\
\hline AU72-1 & $3.555 \pm 0.005$ & $3.200 \pm 0.050$ & $0.000 \pm 0.000$ & $0.000 \pm 0.000$ & $5.140 \pm 0.290$ \\
\hline AU79-1 & $3.535 \pm 0.025$ & $3.365 \pm 0.115$ & $0.120 \pm 0.050$ & $0.000 \pm 0.000$ & $5.110 \pm 0.270$ \\
\hline IN73-1 & $3.595 \pm 0.045$ & $3.090 \pm 0.090$ & $0.000 \pm 0.000$ & $0.000 \pm 0.000$ & $5.040 \pm 0.340$ \\
\hline ID72-1 & $3.480 \pm 0.030$ & $3.215 \pm 0.055$ & $0.000 \pm 0.000$ & $0.000 \pm 0.000$ & $5.160 \pm 0.220$ \\
\hline PH77-1 & $3.490 \pm 0.010$ & $3.170 \pm 0.060$ & $0.000 \pm 0.000$ & $0.000 \pm 0.000$ & $5.070 \pm 0.170$ \\
\hline TW72-1 & $3.520 \pm 0.000$ & $3.345 \pm 0.095$ & $0.065 \pm 0.065$ & $0.000 \pm 0.000$ & $5.100 \pm 0.290$ \\
\hline TW80-1 & $2.895 \pm 0.055$ & $2.320 \pm 0.020$ & $0.390 \pm 0.140$ & $0.035 \pm 0.065$ & $2.010 \pm 0.360$ \\
\hline TW80-2 & $3.605 \pm 0.065$ & $3.260 \pm 0.030$ & $0.050 \pm 0.055$ & $0.020 \pm 0.020$ & $5.085 \pm 0.185$ \\
\hline $\mathrm{TH}$ & $3.450 \pm 0.010$ & $3.305 \pm 0.105$ & $0.000 \pm 0.000$ & $0.000 \pm 0.000$ & $5.165 \pm 0.195$ \\
\hline HW95 & $3.430 \pm 0.000$ & $3.385 \pm 0.085$ & $0.055 \pm 0.055$ & $0.000 \pm 0.000$ & $5.140 \pm 0.270$ \\
\hline HW98 & $3.530 \pm 0.010$ & $3.130 \pm 0.100$ & $0.810 \pm 0.260$ & $0.550 \pm 0.405$ & $5.195 \pm 0.225$ \\
\hline BZ82-1 & $0.500 \pm 0.260$ & $0.100 \pm 0.030$ & $3.310 \pm 0.570$ & $2.945 \pm 0.045$ & $5.005 \pm 0.185$ \\
\hline PR & $0.535 \pm 0.465$ & $0.735 \pm 0.135$ & $3.300 \pm 0.340$ & $2.455 \pm 0.015$ & $4.355 \pm 0.165$ \\
\hline XP21 & $0.030 \pm 0.000$ & $0.007 \pm 0.007$ & $0.013 \pm 0.013$ & $0.000 \pm 0.000$ & $0.013 \pm 0.013$ \\
\hline XP22 & $0.457 \pm 0.052$ & $0.263 \pm 0.034$ & $0.000 \pm 0.000$ & $0.000 \pm 0.000$ & $0.023 \pm 0.012$ \\
\hline XP175 & $0.017 \pm 0.012$ & $0.000 \pm 0.000$ & $0.007 \pm 0.007$ & $0.000 \pm 0.000$ & $0.017 \pm 0.012$ \\
\hline XP202 & $0.033 \pm 0.017$ & $0.017 \pm 0.012$ & $0.010 \pm 0.010$ & $0.000 \pm 0.000$ & $0.017 \pm 0.017$ \\
\hline $\mathrm{NTC}^{\mathrm{b}}$ & $0.220 \pm 0.220$ & $0.360 \pm 0.010$ & $0.000 \pm 0.000$ & $0.000 \pm 0.000$ & $0.400 \pm 0.390$ \\
\hline
\end{tabular}

a Data are the means of two replicates \pm standard error.

b NTC = no DNA template control.

TABLE 4. Cycle threshold values from real-time polymerase chain reaction assays of Phakopsora pachyrhizi and P. meibomiae isolates ${ }^{\mathrm{a}}$

\begin{tabular}{|c|c|c|c|c|c|}
\hline \multirow[b]{2}{*}{ Isolate } & \multicolumn{2}{|c|}{ Ppm1/Ppa2 primers } & \multicolumn{2}{|c|}{ Ppm1/Ppe2 primers } & \multirow{2}{*}{$\frac{\text { Ppm1/Ppm2 primers }}{\text { VIC-probe }}$} \\
\hline & FAM-probe & VIC-probe & FAM-probe & VIC-probe & \\
\hline AU72-1 & $20.17 \pm 0.26$ & $21.14 \pm 0.08$ & $>35.00$ & $>35.00$ & $23.29 \pm 0.02$ \\
\hline AU79-1 & $18.42 \pm 0.14$ & $19.17 \pm 0.10$ & $>35.00$ & $>35.00$ & $21.35 \pm 0.19$ \\
\hline IN73-1 & $19.99 \pm 0.28$ & $20.92 \pm 0.47$ & $>35.00$ & $>35.00$ & $23.77 \pm 0.64$ \\
\hline ID72-1 & $20.09 \pm 0.53$ & $21.22 \pm 0.17$ & $>35.00$ & $>35.00$ & $22.24 \pm 0.23$ \\
\hline PH77-1 & $20.08 \pm 0.06$ & $20.83 \pm 0.43$ & $>35.00$ & $>35.00$ & $22.84 \pm 0.55$ \\
\hline TW72-1 & $18.51 \pm 0.18$ & $19.37 \pm 0.18$ & $>35.00$ & $>35.00$ & $20.32 \pm 0.14$ \\
\hline TW80-1 & $27.71 \pm 0.38$ & $29.35 \pm 0.25$ & $>35.00$ & $>35.00$ & $33.10 \pm 0.12$ \\
\hline TW80-2 & $20.46 \pm 0.68$ & $21.72 \pm 0.54$ & $>35.00$ & $>35.00$ & $23.92 \pm 0.72$ \\
\hline $\mathrm{TH}$ & $19.11 \pm 0.51$ & $20.62 \pm 0.07$ & $>35.00$ & $>35.00$ & $21.86 \pm 0.26$ \\
\hline HW95 & $19.44 \pm 0.21$ & $20.03 \pm 0.09$ & $>35.00$ & $>35.00$ & $22.10 \pm 0.21$ \\
\hline HW98 & $19.68 \pm 0.20$ & $20.36 \pm 0.34$ & $>35.00$ & $>35.00$ & $21.81 \pm 0.12$ \\
\hline BZ82-1 & $>35.00$ & $>35.00$ & $20.37 \pm 0.70$ & $20.61 \pm 0.29$ & $21.69 \pm 0.14$ \\
\hline PR & $>35.00$ & $>35.00$ & $22.53 \pm 0.05$ & $22.61 \pm 0.34$ & $26.20 \pm 0.11$ \\
\hline XP21 & $34.45 \pm 0.30$ & $>35.00$ & $>35.00$ & $>35.00$ & $>35.00$ \\
\hline XP22 & $33.77 \pm 1.23$ & $33.51 \pm 0.21$ & $>35.00$ & $>35.00$ & $>35.00$ \\
\hline XP175 & $>35.00$ & $>35.00$ & $>35.00$ & $>35.00$ & $>35.00$ \\
\hline XP202 & $>35.00$ & $>35.00$ & $>35.00$ & $>35.00$ & $>35.00$ \\
\hline $\mathrm{NTC}^{\mathrm{b}}$ & $>35.00$ & $>35.00$ & $>35.00$ & $>35.00$ & $>35.00$ \\
\hline
\end{tabular}

a Data are the means of two replicates \pm standard error.

b NTC $=$ no DNA template control. 
and Southern blot using the P. meibomiae-specific PCR assay, but no band was detected from the plants infected with $P$. pachyrhizi isolate TW72-1 (Fig. 9B). The PCR assay with the primer set Ppm1/Ppm2 revealed a PCR product from soybean plants infected with either $P$. pachyrhizi isolate TW72-1 or P. meibomiae isolate BZ82-1 (Fig. 9C).

In the $P$. pachyrhizi real-time PCR assay, the DNA sample extracted from soybean infected with $P$. pachyrhizi isolate TW721 had $\triangle \mathrm{RQ}$ values of 3.095 and 2.810 with the FAM- and VICprobes, respectively (Fig. 10A and C). The DNA sample from soybean infected with $P$. meibomiae isolate BZ82-1 had $\triangle \mathrm{RQ}$ values of 0.290 with the FAM-probe and 0.050 with the VICprobe (Fig. 10A and C). The $\mathrm{Ct}$ values of the plants infected with TW72-1 were $18.57 \pm 0.14$ (FAM-probe) and $20.73 \pm 0.21$ (VICprobe), whereas the $\mathrm{Ct}$ values of the plants infected with BZ82-1 and the noninoculated control plants were greater than 35 for both the FAM- and VIC-probes. On the other hand, the DNA sample extracted from soybean infected with P. meibomiae isolate BZ821 had $\triangle \mathrm{RQ}$ values of 2.970 with the FAM-probe and 3.085 with the VIC-probe using the P. meibomiae real-time PCR assay (Fig. 10B and D). The DNA sample from soybean infected with $P$. pachyrhizi isolate TW72-1 had $\triangle \mathrm{RQ}$ values of 0.320 and 0.245 with the FAM- and VIC-probes, respectively (Fig. 10B and D). The $\mathrm{Ct}$ values of the plants infected with isolate BZ82-1 were $19.05 \pm 0.04$ (FAM-probe) and 20.89 \pm 0.10 (VIC-probe), whereas the $\mathrm{Ct}$ values of the plants infected with TW72-1 and the noninoculated control plants were greater than 35 for both the FAM- and VIC-probes. In the real-time PCR assays with the primer set Ppm1/Ppm2, the DNA samples extracted from soybean infected with either $P$. pachyrhizi isolate TW72-1 or $P$. meibomiae isolate BZ82-1 had $\triangle \mathrm{RQ}$ values of 4.450 and 4.225 with the VICprobe, respectively (Fig. 10E). The Ct values of the plants infected with isolates TW72-1 and BZ82-1 were $22.07 \pm 0.18$ and $22.14 \pm$ 0.28 , respectively, whereas the $\mathrm{Ct}$ value of noninoculated control plants was greater than 35 .

\section{DISCUSSION}

Accurate and timely diagnoses of plant diseases are extremely important so that appropriate control measures and eradication procedures can be implemented quickly. Disease symptoms often aid with making decisions, but a definitive diagnosis requires unambiguous pathogen identification. A major mission of this laboratory is to examine new technologies and develop novel methods for the detection and identification of exotic plant pathogens that are deemed significant threats to U.S. agriculture.

Soybean rust has been identified as a potentially devastating disease if the pathogen were to gain entry and become established in the United States. Soybean rust is caused by two morphologically similar species of Phakopsora: $P$. pachyrhizi and $P$. meibomiae (18). Although both pathogens damage plants, $P$. pachyrhizi is more aggressive and causes considerably greater yield loss (23). Previously, isozyme analysis was successful in discriminating between these two Phakopsora spp. (8). However, this method is slow and is not useful for detecting and identifying the pathogens in infected plant material.

Classical PCR methods have been described for the identification and detection of numerous plant pathogens (16). Moreover, several real-time fluorescent PCR assays have been developed recently for bacterial (21), viral $(19,22)$, and fungal plant pathogens $(6,14,27)$. Real-time PCR has several advantages compared with classical PCR. First, it combines the sensitivity of PCR with the specificity of nucleic acid hybridization. Second, there is no need for agarose gels and the subsequent Southern blot hybridization steps that are necessary to confirm the identity of PCR products. Third, up to four different fluorescent dyes can be incorporated in a single reaction that allows for multiplexed reactions using different probes for either the same or different pathogens. Finally, many samples can be assayed simultaneously (up to 96 with the ABI Prism 7700 Sequence Detection System), and the assays can be completed within 2 to $3 \mathrm{~h}$. Recently, a portable analytical thermal cycling instrument, the Smart Cycler (Cepheid, Inc., Sunnyvale, CA), was introduced for conducting real-time PCR directly in the field $(4,5)$. This would negate the requirement for sending

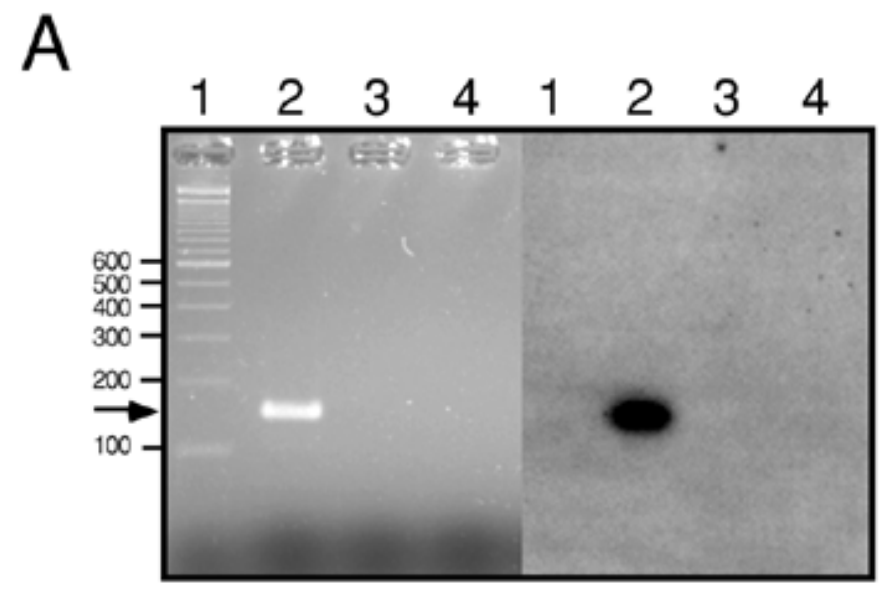

B

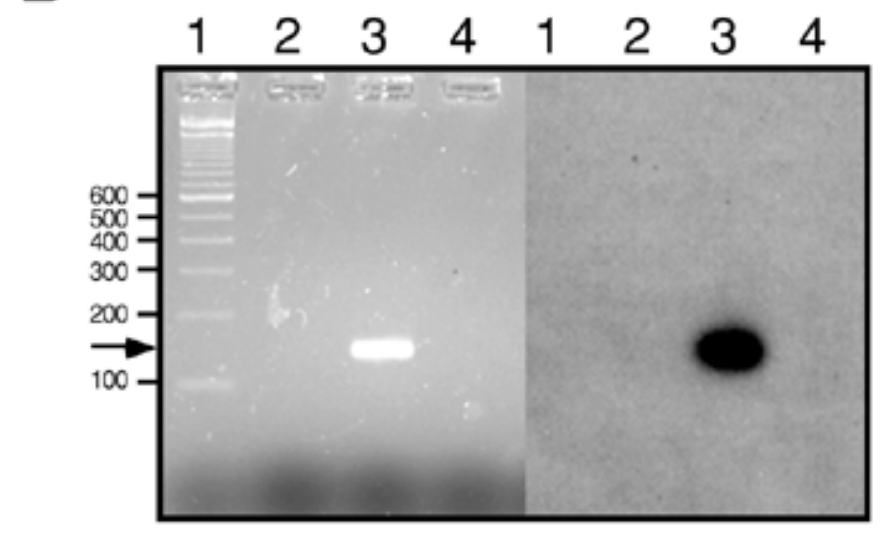

C

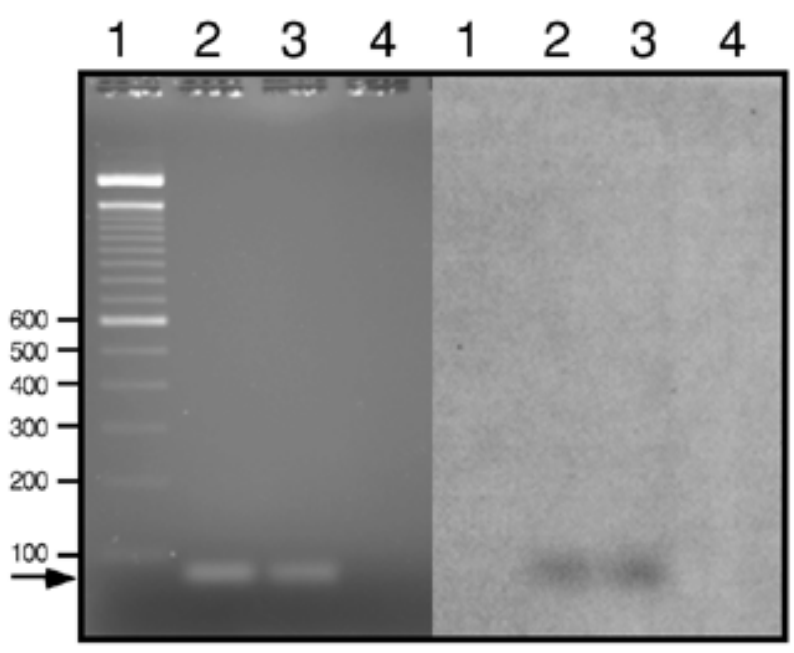

Fig. 9. Detection of Phakopsora pachyrhizi and P. meibomiae from infected leaves using classical polymerase chain reaction (PCR). A, Agarose gels and Southern blots of $P$. pachyrhizi-specific assay using the primer sets Ppm1/Ppa2, B, . meibomiae-specific assay with the primer set Ppm1/Pme2, and $\mathbf{C}$, the nonspecific primers Ppm1/Ppm2. Lane 1 = molecular weight markers (100 bp), $2=$ soybean infected with $P$. pachyrhizi isolate TW72-1, $3=$ soybean infected with P. meibomiae isolate BZ82-1, and $4=$ healthy soybean. PCR products are indicated by arrows. 
samples to the laboratory for analysis, which would result in significantly more rapid diagnoses.

The PCR assays described here provide a new method for the identification and discrimination of the soybean rust pathogens $P$. pachyrhizi and P. meibomiae, especially when diagnosticians are presented only with infected plant material. The ability of the PCR assays to differentiate between $P$. pachyrhizi and $P$. meibomiae is attributable to the nucleotide sequence divergence that occurs within the ITS region of these two species. The PCR primers we designed capitalize on these differences. To further expedite the classical PCR assays, fluorescent probes were developed for use with the $P$. pachyrhizi- and $P$. meibomiae-specific primers in realtime PCR assays. The real-time fluorescent PCR assays are robust, rapid, and allow for high sample throughput (up to 96 samples at one time). Using crude preparations of germinating urediniospores, the $P$. pachyrhizi-specific primers $\mathrm{Ppm} 1 / \mathrm{Ppa} 2$ correctly identified 11 of $11 P$. pachyrhizi isolates, whereas the $P$. meibomiae-specific primer pair combination Ppm1/Pme2 detected both of the $P$. meibomiae isolates. From infected soybean leaves, an accurate diagnosis can be made in less than $5 \mathrm{~h}$ with the real-time PCR assays. Purified DNA was extracted in less than $2 \mathrm{~h}$ with a commercial DNA extraction kit, and the real-time PCR assays were set up and performed by a sequence detection system in less than 2.5 h. No isolation or purification of suspect organisms from infected tissue is necessary, nor is specialized mycological training required in order to perform the real-time PCR assays.
A

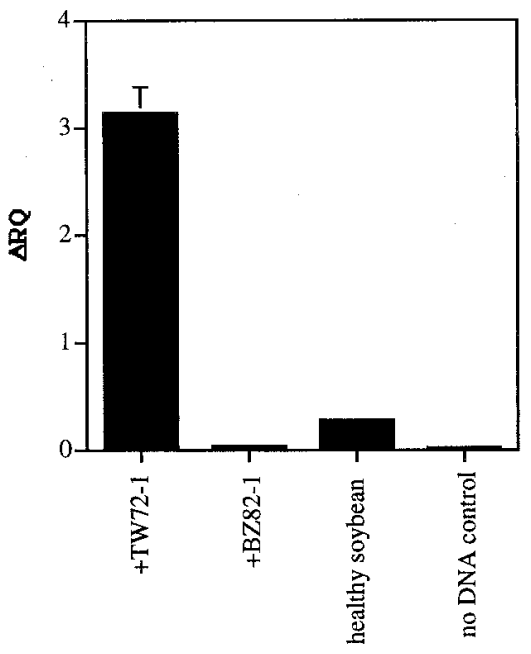

Sample

\section{B}

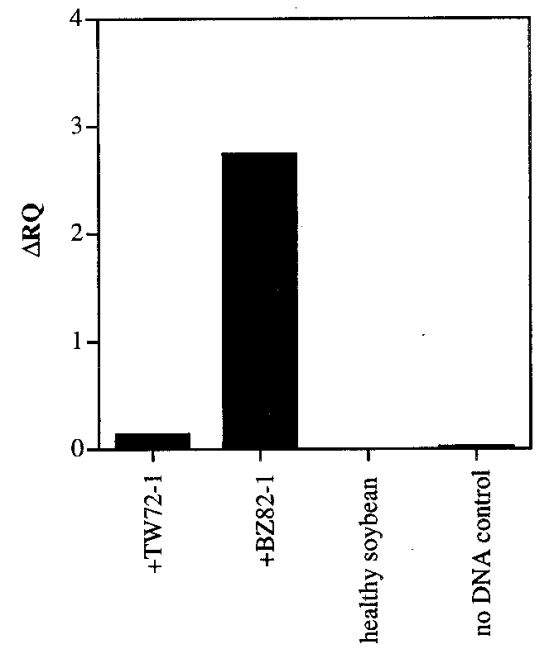

Sample

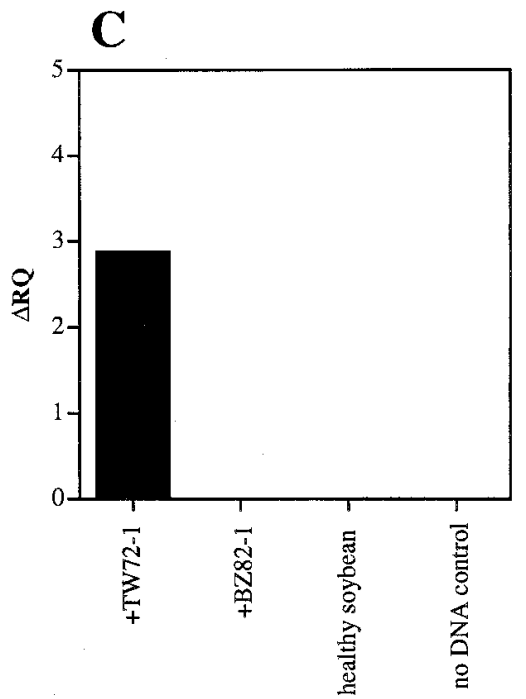

Sample

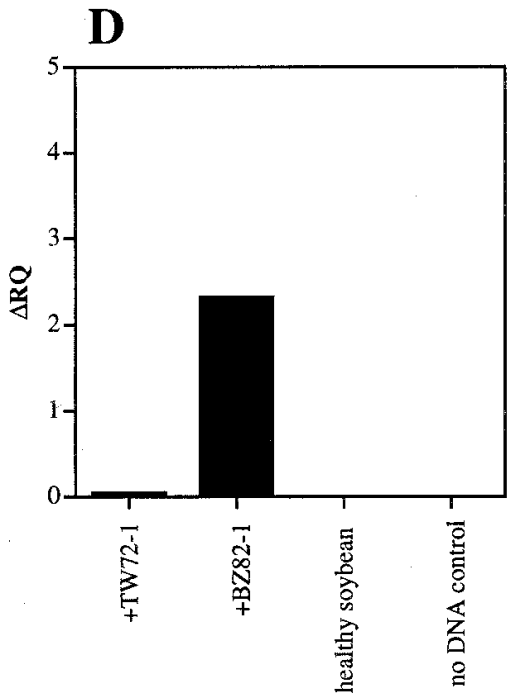

Sample

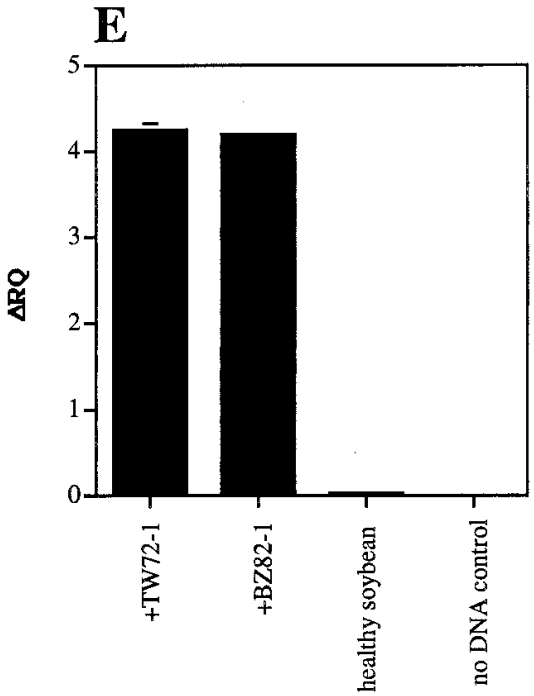

Sample

Fig. 10. Detection of Phakopsora pachyrhizi and P. meibomiae from infected leaves using real-time polymerase chain reaction (PCR). PCR assays were conducted for 35 cycles with a TaqMan sequence detection system (ABI Prism 7700) with A, P. pachyrhizi-specific flanking primers Ppm1/Ppa2 with a 5'-FAMlabeled internal probe sequence, B, P. meibomiae-specific flanking primers Ppm1/Pme2 with a $5^{\prime}$-FAM-labeled internal probe sequence, C, $P$. pachyrhizi-specific flanking primers Ppm1/Ppa2 with a 5'-VIC-labeled internal probe sequence, D, P. meibomiae-specific flanking primers Ppm1/Pme2 with a 5'-VIC-labeled internal probe sequence, or E, the primers Ppm1/Ppm2, which amplify a PCR product from both $P$. pachyrhizi and P. meibomiae with a 5'-VIC-labeled internal probe sequence. The left axis $(\triangle \mathrm{RQ})$ is the change in fluorescence that is a measure of probe cleavage efficiency, and the bottom axis is the PCR cycling stage. The $\triangle \mathrm{RQ}$ values are the means of two independent experiments with duplicate DNA samples. Error bars represent standard errors of the means. $+\mathrm{TW} 72-1=$ soybean infected with $P$. pachyrhizi isolate TW72-1, +BZ82-1 = soybean infected with $P$. meibomiae isolate BZ82-1, healthy soybean $=$ noninoculated soybean, and NTC = no DNA template control. 
Both the FAM- and VIC-labeled probes yielded similar levels of fluorescence when used in either of the Phakopsora sp.-specific real-time PCR assays. The VIC-labeled probe and the Ppm1/Ppm2 primers were designed to sequences within in the 5.8S rDNA so they could be used to detect the presence of either Phakopsora spp. from any source material. The detection limits of the two Phakopsora spp.-specific assays are similar. The 82-bp PCR product amplified using primers Ppm1 and Ppm2 is highly conserved among a number of different genera of fungi including species of Armillaria, Cronartium, Melampsora, Peridermium, Puccinia, Rhizoctonia, and Uromyces. Because the sequence of the VICprobe and the Ppm2 primer is virtually identical among these species, slight modification to the Ppm1 primer sequence would extend the application of this real-time PCR assay to these other fungi. For example, the last four nucleotides could be removed at the $3^{\prime}$ end of Ppm1 to create a primer that would match exactly with sequences in these fungi.

Soybean rust is a devastating disease in several soybean-growing regions of Asia, Australia, and Africa, and it is a potential threat to other countries where soybeans are grown. The PCR assays we developed can be used to detect $P$. pachyrhizi from infected plant tissue, with or without urediniospores, and facilitate surveying soybean fields and other plant species that may serve as alternative hosts for either of the Phakopsora spp. Early detection, coupled with proper application of fungicides, would slow the spread of the pathogen and reduce yield losses.

\section{ACKNOWLEDGMENTS}

This work has been supported by USDA-ARS CRIS 1920-22000-02300D. We thank D. Luster, P. Tooley, and N. Schaad for critically reviewing the manuscript; E. Kilgore and C. Levy who collected and sent rust samples from Hawaii and Zimbabwe, respectively; and K. R. Bromfield for his insight and interest in soybean rust, and his enthusiasm in this research.

\section{LITERATURE CITED}

1. Asian Vegetable Research and Development Center. 1987. Bibliography of soybean rust, 1895-1986. AVRDC (Asian Veg. Res. Dev. Cent.) Library Bibliography Series 4. Publication No. 87-277.

2. Asian Vegetable Research and Development Center. 1992. Annotated bibliography of soybean rust (Phakopsora pachyrhizi Sydow). AVRDC (Asian Veg. Res. Dev. Cent.) Library Bibliography Series 4-1. Publication No. 92-372.

3. Ausubel, F. M., Brent, R., Kingston, R. E., Morre, D. D., Seidman, J. G., Smith, J. A., and Struhl, K., eds. 1987. Current Protocols in Molecular Biology. John Wiley \& Sons, New York.

4. Belgrader, P., Benett, W., Hadley, D., Richards, J., Statton, P., Mariella, R., Jr., and Milanovich, F. 1999. Detection and identification of bacteria in 7 minutes using a portable PCR instrument. Science 284:449-450.

5. Belgrader, P., Young, B., Yuan, B., Primeau, M., Christel, L. A., Pourahmadi, F., and Northrup, M. A. 2001. A battery-powered notebook thermal cycler for rapid multiplex real-time PCR analysis. Anal. Chem. 73:286-289.

6. Bohm, J., Hahn, A., Schubert, R., Bahnweg, G., Adler, N., Nechwatal, J., Oehlmann, R., and Oswald, W. 1999. Real-time quantitative PCR: DNA determination in isolated spores of the mycorrhizal fungus Glomus mosseae and monitoring of Phytophthora infestans and Phytophthora citri- cola in their respective host plants. J. Phytopathol. 147:409-416.

7. Bonde, M. R., Melching, J. S., and Bromfield, K. R. 1976. Histology of the susceptible pathogen relationship between Glycine max and Phakopsora pachyrhizi, the cause of soybean rust. Phytopathology 66:12901294.

8. Bonde, M. R., Peterson, G. L., and Dowler, W. M. 1988. A comparison of isozymes of Phakopsora pachyrhizi from the Eastern Hemisphere and the New World. Phytopathology 78:1491-1494.

9. Bromfield, K. R. 1984. Soybean Rust. Monogr. 11. The American Phytopathological Society, St. Paul, MN.

10. Brosius, J., Palmer, M. L., Kennedy, P. J., and Noller, H. F. 1978. Complete nucleotide sequence of a 165 ribosomal RNA gene from Escherichia coli. Proc. Natl. Acad. Sci. USA 75:4801-4805.

11. Cherry, E., and Peet, C. E. 1966. An efficient device for the rapid collection of fungal spores from infected plants. Phytopathology 56:1102-1103.

12. Devereaux, J., Haeberli, P., and Smithies, O. 1984. A comprehensive set of sequence analysis programs for the VAX. Nucleic Acids Res. 12:387395.

13. Frederick, R. D., Snyder, C. L., Peterson, G. L., and Bonde, M. R. 2000. Detection and discrimination of the soybean rust pathogens Phakopsora pachyrhizi and Phakopsora meibomiae using PCR. (Abstr.) Phytopathology 90(suppl.):S25.

14. Frederick, R. D., Snyder, K. E., Tooley, P. W., Berthier-Schaad, Y., Peterson, G. L., Bonde, M. R., Schaad, N. W., and Knorr, D. A. 2000. Identification and differentiation of Tilletia indica and T. walkeri using the polymerase chain reaction. Phytopathology 90:951-960.

15. Hartman, G. L., Sinclair, J. B., and Rupe, J. C., eds. 1999. Compendium of Soybean Diseases. 4th ed. The American Phytopathological Society, St. Paul, MN.

16. Henson, J. M., and French, R. 1993. The polymerase chain reaction and plant disease diagnosis. Annu. Rev. Phytopathol. 31:81-109.

17. Melching, J. S., Bromfield, K. R., and Kingsolver, C. H. 1983. The plant pathogen containment facility at Frederick, Maryland. Plant Dis. 67:717722.

18. Ono, Y., Buritica, P., and Hennen, J. F. 1992. Delimitation of Phakopsora, Physopella, and Cerotelium and their species on Leguminosae. Mycol. Res. 96:825-850.

19. Roberts, C. A., Dietzgen, R. G., Heelan, L. A., and Maclean, D. J. 2000. Real-time RT-PCR fluorescent detection of tomato spotted wilt virus. J. Virol. Methods 88:1-8.

20. Schaad, N. W. 1988. Initial identification of common genera: A Laboratory Guide for Identification of Plant Pathogenic Bacteria. The American Phytopathological Society, St. Paul, MN.

21. Schaad, N. W., Berthier-Schaad, Y., Sechler, A., and Knorr, D. 1999. Detection of Clavibacter michiganensis subsp. sepedonicus in potato tubers by BIO-PCR and an automated real-time fluorescence detection system. Plant Dis. 83:1095-1100.

22. Schoen, C. D., Knorr, D., and Leone, G. 1996. Detection of potato leafroll virus in dormant potato tubers by immunocapture and a fluorogenic 5' nuclease RT-PCR assay. Phytopathology 86:993-999.

23. Sinclair, J. B., and Hartman, G. L., eds. 1996. Soybean rust workshop. College of Agricultural, Consumer, and Environmental Sciences. Natl. Soybean Res. Lab. Publ. 1.

24. Tschanz, A. T., and Shanmugasundaram, S. 1985. Soybean rust. Pages 562-567 in: Proc. World Soybean Res. Conf., III. R. Shibles, ed. Westview Press, Boulder, CO.

25. White, T. J., Bruns, T., Lee, S., and Taylor, J. 1990 Amplification and direct sequencing of fungal ribosomal RNA genes for phylogenetics. Pages 315-322 in: PCR Protocols. M. A. Innis, D. H. Gelfand, J. J. Sninski, and T. J. White, eds. Academic Press, San Diego, CA.

26. Yang, X. B., Dowler, W. M., and Royer, M. H. 1991. Assessing the risk and potential impact of an exotic plant disease. Plant Dis. 75:976-982.

27. Zhang, A. W., Hartman, G. L., Curio-Penny, B., Pedersen, W. L., and Becker, K. B. 1999. Molecular detection of Diaporthe phaseolorum and Phomopsis longicolla from soybean seeds. Phytopathology 89:796-804. 